\title{
Rumen and total intestinal tract digestibility of protein and amino acids from different roughages, determined in situ
}

\author{
Beata Skiba1, M.R. Weisbjerg and T. Hvelplund \\ The National Institute of Animal Science, Research Centre Foulum \\ P.O. Box 39, DK-8830 Tjele, Denmark \\ 'The Kielanowski Institute of Animal Physiology and Nutrition, \\ Polish Academy of Sciences \\ 05-110 Jablonna, Poland
}

(Received 30 May 1996; accepted 13 September 1996)

\begin{abstract}
Eight different roughages (clover grass silage, 2 samples of fresh clover grass, fresh ryegrass, winter wheat whole crop silage, pea whole crop silage, dried grass and goats ruc) were examined for effective degradability in the rumen and total tract digestibility of individual amino acids (AA), total AA and crude protein using in situ method. Effective degradabilities calculated at a rumen fractional outflow rate of $5 \% / \mathrm{h}$, were higher for crude protein than for total AA (the differences ranging from 1.9 to 4.1 percentage points). Arginine was the least degradable amino acid, particularly in silage and in short rumen incubations, although cysteine and phenylalanine also tended to be less degraded than total AA. The most degradable amino acids were alanine and proline in silages, and cysteine, aspartic acid and glutamic acid in the other roughages.

Disappearance of total AA from mobile bags containing samples of feeds after $16 \mathrm{~h}$ preincubation in the rumen varied from $79.8 \%$ in dried grass $1095.9 \%$ in fresh clover grass, and was generally similar to the disappearance of crude protein, $79.7-96.3 \%$, respectively. In most of the exarnined roughages, cystine and glycine disappeared the least, and glutamic acid, aspartic acid and alanine the most from mobile bags, as compared with total AA.
\end{abstract}

KEY WORDS: rumen, roughages, amino acid profile, protein, ruminal degradability, intestinal digestibility

\section{INTRODUCTION}

The amino acids available for absorption in ruminants are derived from dietary protein which has escaped rumen degradation and from microbial 
protein synthesized in the rumen. Since the amount of microbial protein synthesized in the rumen is inadequate to fulfill the AA requirement for high producing cattle, the quantity of feed protein escaping rumen degradation and its amino acid composition, particularly the amount of the most limiting amino acids, play an important role in covering an animal's AA requirements. The degradability of crude protein has been used to predict the degradation of individual AA and their supply to the duodenum (Rulquin and Verite, 1993), although results from some experiments suggest that the degradability of total AA can deviate from that of crude protein, and that variations in degradation can occur among individual amino acids (Susmel et al., 1989; Boila and Ingalls, 1994; Skórko-Sajko et al., 1994; Cozzi et al., 1995; Dakowski et al., 1996). Therefore, prediction of the amount of feed AA supplied at the duodenum based on the original AA composition of the feed and degradation of crude protein can be inaccurate.

The digestibility of protein and individual AA is the second important factor affecting the amount of AA which potentially could be absorbed from the small intestine. Most protein evaluation systems (ARC, 1984; Madsen, 1985; NKJ, 1985 ; NRC, 1985) assume constant intestinal digestibilities of rumen undegraded dietary AA, which are about $80 \%$, but, on the other hand, some studies (Hvelplund, 1985; Masoero et al., 1994) indicate that intestinal digestibility of rumen undegraded dietary protein (RUDP) and AA for some feeds is lower than $80 \%$ and could vary between individual AA. Information on the digestibility of total and individual AA in different feed residues, which escaped degradation in the rumen, is still limited (Hvelplund and Hesselholt, 1987; Boila and Ingalls, 1994; Erasmus et al., 1994; Skórko-Sajko et al., 1994). Therefore, reliable measures of RUDP, its AA content and intestinal digestibility are necessary.

The aim of the present study was to determine the rumen degradability of crude protein, total and individual AA for eight different roughages after 8, 24 and $72 \mathrm{~h}$ incubation in the rumen and total digestibility estimated as disappearance from mobile bags (including preincubation for $16 \mathrm{~h}$ in the rumen) of crude protein and AA of these feeds. The degradability and disappearance from mobile bags of total and individual amino acids were then compared with values estimated for crude protein.

\section{MATERIAL AND METHODS}

\section{Feeds}

Eight different roughages (clover grass silage, 2 samples of fresh clover grass, fresh ryegrass, winter wheat whole crop silage, pea whole crop silage, dried grass and goats rue) were used in this experiment, and their chemical composition is 
presented in Table 1. All samples were freeze- dried and milled through a $1.5 \mathrm{~mm}$ screen for in situ method, and through a $1 \mathrm{~mm}$ screen for other chemical analysis. Feed samples were analysed for dry matter, nitrogen, ash and crude fibre content according to conventional methods (AOAC, 1990). Amino acids were analysed according to Mason et al. (1980).

\section{Animals}

Three rumen cannulated dry cows, fed twice daily with a diet composed of clover grass hay (2/3) and concentrate (1/3), were used for estimation of rumen degradability and preincubation of mobile bags. For the mobile bag procedure three doudenal fistulated cows, fed according to milk production, were used.

\section{Degradability}

Rumen degradabilities of crude protein and AA were determined using the nylon bag technique (Madsen and Hvelplund, 1994). Feed samples were incubated in the rumen for $0,8,24$ and $72 \mathrm{~h}$ in nylon bags $(7 \times 10 \mathrm{~cm}$ with pore size $36 \times 36 \mathrm{~mm}$ ). The bags were inserted into the rumen during the morning feeding. The number of bags and the amount of samples incubated in the rumen were adjusted to obtain approximately $10 \mathrm{mg} \mathrm{N}$ per incubation time in the pooled undegraded residues. After each incubation time the bags were frozen until all bags had been collected. They were then washed in cold water in a washing machine for $15 \mathrm{~min}$. Before chemical analysis, the residues from rumen incubations were treated for $5 \mathrm{~min}$ with a stomacher and rewashed through the nylon bags to remove microbial contamination from the residues in the bags. The residues were then transferred to $\mathrm{N}$-free filter paper, freeze-dried and hydrolyzed for AA determination. Nitrogen was also determined in the hydrolysate using a micro Kjeldahl method. To avoid uncontrolled boiling, the samples were hydrolyzed in an autoclave at $110^{\circ} \mathrm{C}$.

\section{Measurements of water-solubility and washing loss}

Loss of small particles was estimated as the difference between the loss from the nylon bags which were washed without rumen incubation $(0 \mathrm{~h})$ and the loss of true water soluble material through filter paper.

\section{Crude protein and AA disappearance from the mobile bags}

Total tract digestibility was estimated by the mobile bag technique according to Hvelplund et al. (1992) using nylon bags with a pore size of $11 \mathrm{x} 11 \mathrm{~mm}$. The 
heat sealed bags with feed samples were preincubated in the rumen for $16 \mathrm{~h}$, acidified in an $\mathrm{HCl}$ solution ( $\mathrm{pH} 2.4$ ) for $1 \mathrm{~h}$ to adjust $\mathrm{pH}$ and then incubated in a pepsin- $\mathrm{HCl}$ solution (200 mg pepsin (1:10000 Orthana 23208) dissolved in 21 of $0.004 \mathrm{~N} \mathrm{HCl}, \mathrm{pH} 2.4$ ) while being shaken in a waterbath for $2 \mathrm{~h}$ at $40^{\circ} \mathrm{C}$. After incubation in pepsin- $\mathrm{HCl}$ solution the bags were introduced into the intestine through the duodenal cannulae ( 15 bags per cow per day) and the bags were recovered from the faeces after passage through the intestine. After recovery, all of the bags were washed in a washing machine for $15 \mathrm{~min}$. The residues were pooled to form a sample containing approximately $10 \mathrm{mg} \mathrm{N}$ and transferred to $\mathrm{N}$-free filter paper for $\mathrm{N}$ and $\mathrm{AA}$ analysis as described for rumen residues.

\section{Calculations}

Degradability of protein in the samples after rumen incubation was calculated from the disappearance of $\mathrm{N}$ from the bags. Effective degradability (ED) was estimated according to Ørskov and McDonald (1979) using Proc NLIN (SAS, 1985). ED was corrected for loss of small particles according to Weisbjerg et al. (1990). Total tract digestibility of protcin and amino acids was calculated as the disappearance from the bags after rumen incubation and passage through the intestine.

\section{RESULTS}

The chemical composition of the different roughages used in the experiment is presented in Table 1. The $\mathrm{N}$ content in $\mathrm{DM}$ varied from 1.4 in winter wheat whole crop silage to $4.7 \%$ in fresh clover grass. The content of total AA ( $\mathrm{g} \mathrm{AAN} / 100 \mathrm{~g} \mathrm{~N}$ ) in the tested feeds (Table 2) ranged from 49.1 in winter wheat whole crop silage to $73.1 \%$ in fresh clover grass. Differences in the proportion of individual AA between the tested feeds were also found as shown in Table 2. The proportion of lysine ( $\mathrm{g} \mathrm{AA}-\mathrm{N} / 100 \mathrm{~g} \mathrm{~N}$ ) varied from 2.8 in winter wheat whole crop silage to 6.5 in fresh clover grass; methionine varied from 0.6 in pea whole crop silage to 1.06 in fresh ryegrass.

The intra-assay coefficient of variation of analysed AA was low and never exceeded $1.3 \%$. This suggests that the method used to analyse AA (Mason et al., 1980) was precise enough and did not effect the recovery of any amino acid in feed samples, so the results presented in this study are reliable.

Water solubility, degradabilities at different incubation times and effective degradabilities calculated using a fractional rumen outflow rate of 0.05 , both uncorrected and corrected for particle loss of $\mathrm{N}$, total AA and individual AA, are 
TABLE 1

Chemical composition of the roughages

\begin{tabular}{lrcc}
\hline & \multicolumn{3}{c}{$\%$ of DM } \\
\cline { 2 - 4 } & ash & nitrogen & crude fibre \\
\hline Clover grass silage & 9.2 & 3.13 & 24.9 \\
Fresh clover grass 1 & 9.4 & 3.61 & 18.8 \\
Fresh ryegrass & 8.7 & 3.56 & 25.5 \\
Fresh clover grass 2 & 10.5 & 4.73 & 16.5 \\
Winter wheat whole crop silage & 5.3 & 1.43 & 23.7 \\
Pea whole crop silage & 7.1 & 2.53 & 21.0 \\
Dried grass & 14.3 & 2.64 & 26.7 \\
Goats rue (Galega officinalis) & 7.4 & 2.84 & 30.9 \\
\hline
\end{tabular}

shown in Tables $3,4,5$ and 6 . Water solubility of individual and total AA was generally lower than solubility of crude protein. Ruminal nitrogen and AA degradability increased with increasing rumen incubation time. For all feedstuffs the effective degradability of crude protein was higher than the results obtained for total AA; the differences ranged between 1.9 to 4.1 percentage points, except for dried grass, for which the effective degradability of crude protein was 9.5 percentage points higher than the effective degradability of total AA. The differences between effective degradability of crude protein or AA with and without correction for particle loss were similar. There were several notable differences in the degradability and effective degradability among individual amino acids within a feed, especially for short rumen incubation times $(8$ and $24 \mathrm{~h}$ ) (Tables 3-6). Arginine originating from silage (clover grass silage, winter wheat whole crop silage and pea whole crop silage) seemed to be the amino acid which was most resistant to rumen degradation; its rumen degradability (especially for short incubation times) and effective degradability were lower than for the other individual amino acids, total AA and crude protein (Table 3 and 5). Arginine from fresh forages had a similar or slightly lower effective degradability, in comparison with the effective degradability of total AA and crude protein. Similarly as for arginine, the effective degradability of cystine and phenylalanine in the silages tended to be lower than that of total AA. The exception was winter wheat whole crop silage, in which effective degradability of phenylalanine was higher than the effective degradability of total AA. The most degradable amino acids in the silages were alanine and proline, although aspartic acid and glutamic acid also had high effective degradabilities. In the other feeds, cystine, aspartic acid and glutamic acid tended to have higher effective degradabilities, while isoleucine, leucine, phenylalanine and glycine tended to have lower effective degradabilities than total AA. 


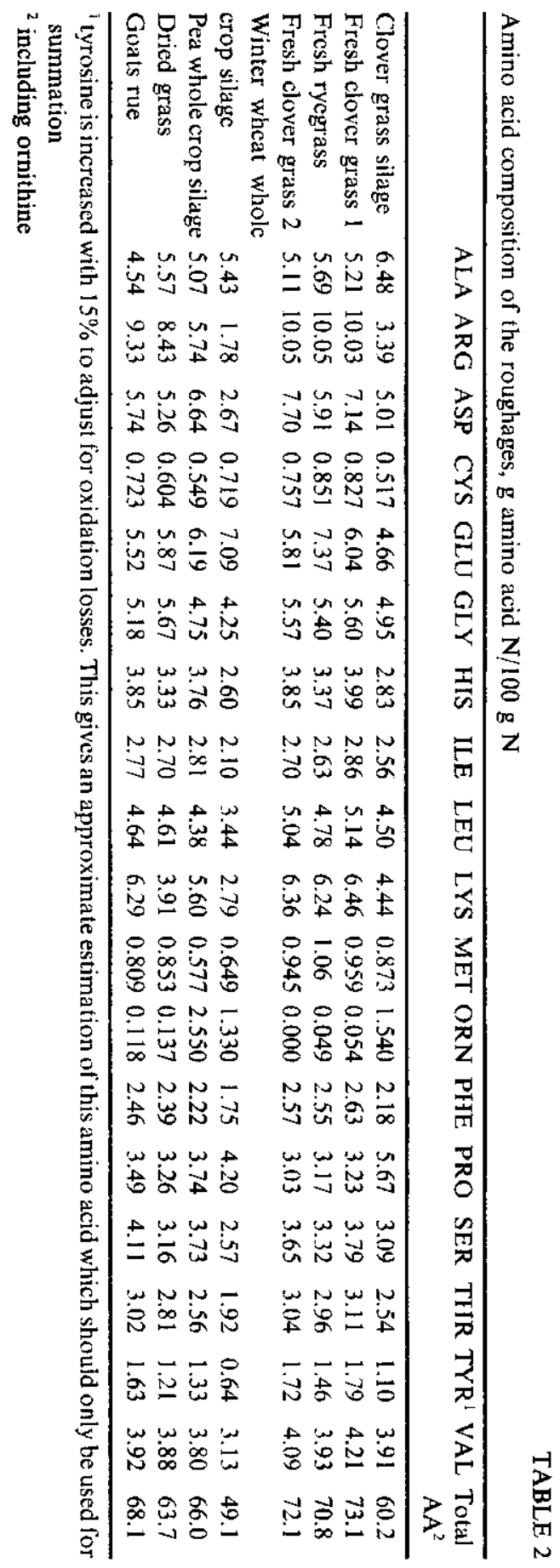


The effective degradabilities of lysine and methionine were generally similar to that of total AA. Only in dried grass were the effective degradabilities of lysine and methionine lower than total AA, but of other amino acids, such as phenylalanine, isoleucine and leucine from dried grass also had lower effective degradabilities compared with total AA.

Total tract digestibilities of crude protein, individual and total AA measured as disappearance from a mobile bag, including a $16 \mathrm{~h}$ preincubation in the rumen, are shown in Table 7. Total AA disappeared in a proportion similar to that of crude protein (the differences varied from 0.1 to 1.6 percentage points), and in most feedstuffs the disappearance of lysine and methionine were similar to total AA disappearance. Cystine (77.2-95.7\%) and glycine (77.6-93.8\%) tended to have a lower disappearance compared to total AA (79.8-95.9\%), although it varied depending on the kind of feeds and was lowest in dried grass and goats ruc. Dried grass generally had the lowest disappearance of total $(79.8 \%)$ and individual AA, especially of methionine $(74.9 \%)$, phenylalanine $(74.8 \%)$ and cysteine $(77.7 \%)$, compared with results obtained for the other fecdstuffs. The highest disappearance was observed for glutamic acid, aspartic acid and alanine. For fresh clover grass and fresh ryegrass, the disappearance of arginine was also high, ranging from 95.3 to $97.7 \%$. In silages, except pea whole crop silage (94.3), arginine disappearance was low $(72.4-89.9 \%)$.

\section{DISCUSSION}

The amount and availability of the most limiting amino acids in rumen undegradable protein play an important role in covering the AA requirements of high producing animals (Schwab et al., 1992). In the French system for prediction of lysine and methionine absorption (Rulquin and Verite, 1993), it is assumed that the AA profile of original feed protein is equal to the AA profile of undegraded feed protein, as found by Gancv et al. (1979), Weakley et al. (1983) and Teller et al. (1985). This means that estimated crude protein degradability is also suitable for prediction of the degradability of individual AA and thereby the supply with AA to the small intestine.

The results obtained for eight different roughages in this study showed that effective degradability of total AA was lower than that estimated for crude protein. This means that the use of crude protein degradability as an estimate for AA degradability can result in overestimation, and thereby an underestimation of the AA proportion in the RUDP reaching the small intestine. Contradictory to this, Skórko-Sajko et al. (1994) found similar degradabilities for crude protein and total $\Lambda \mathrm{A}-\mathrm{N}$ after 4 and $16 \mathrm{~h}$ incubation of four roughages (cocksfoot, vetch wholc crop, clover grass and lucerne) showing that more notable differences 


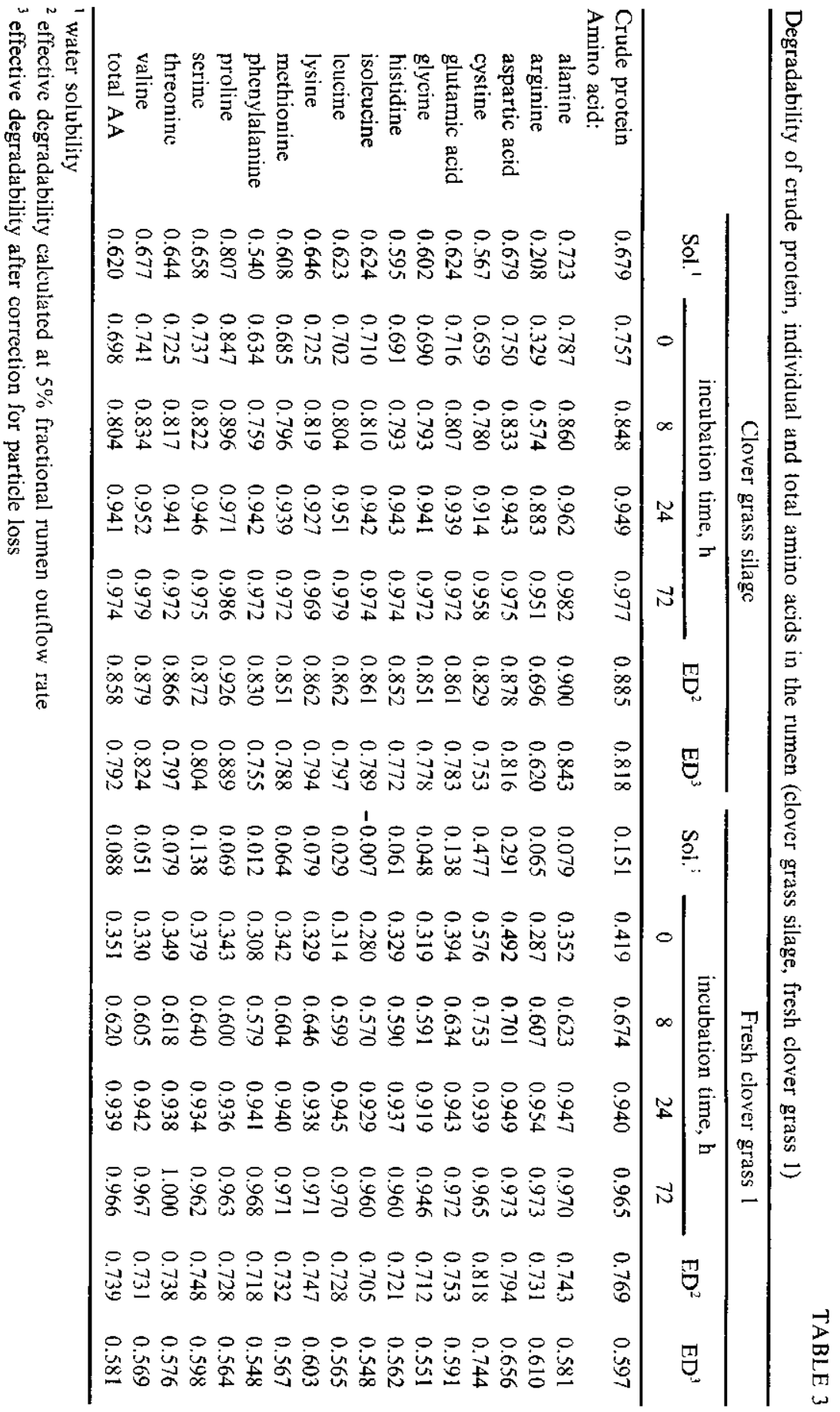




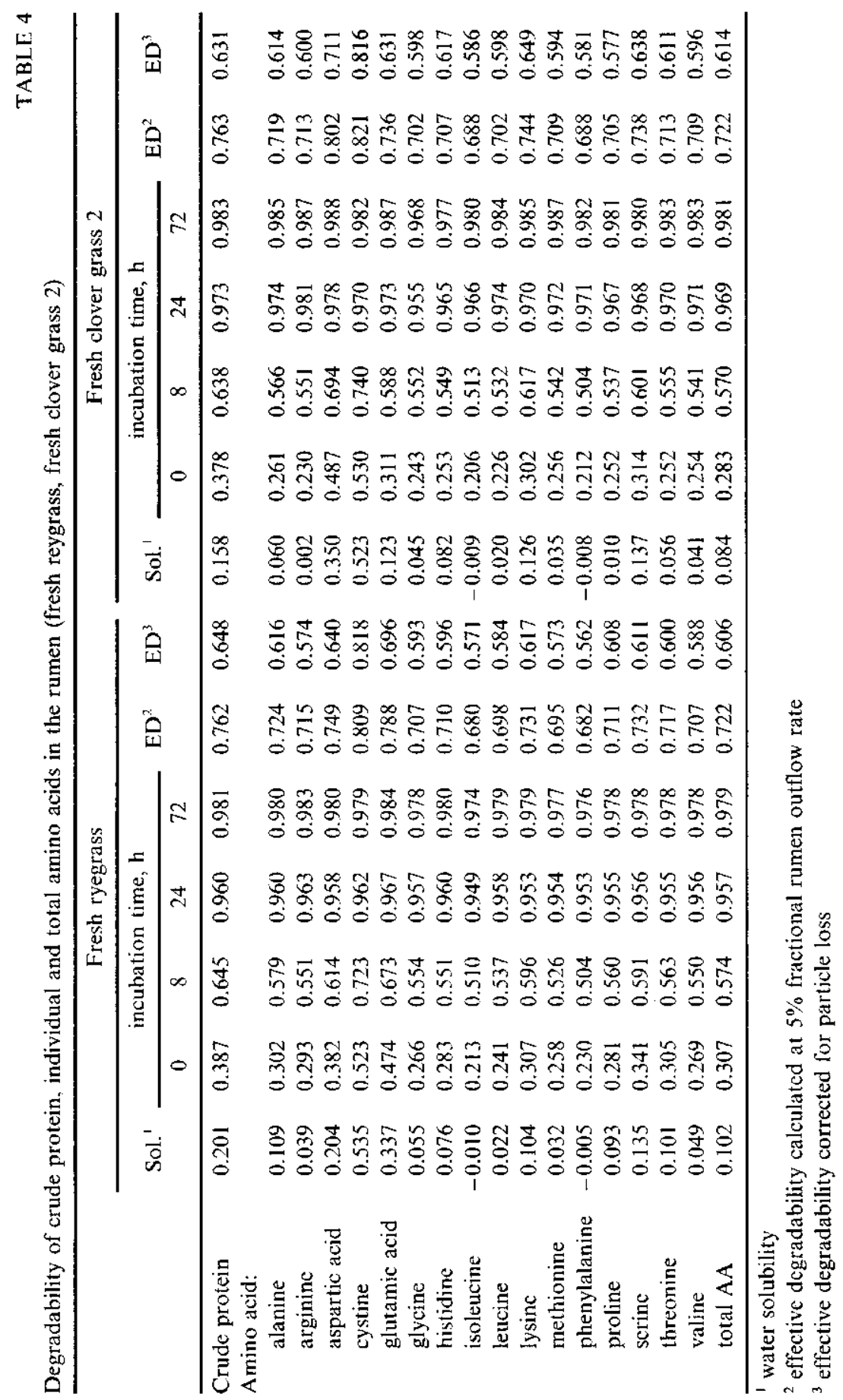




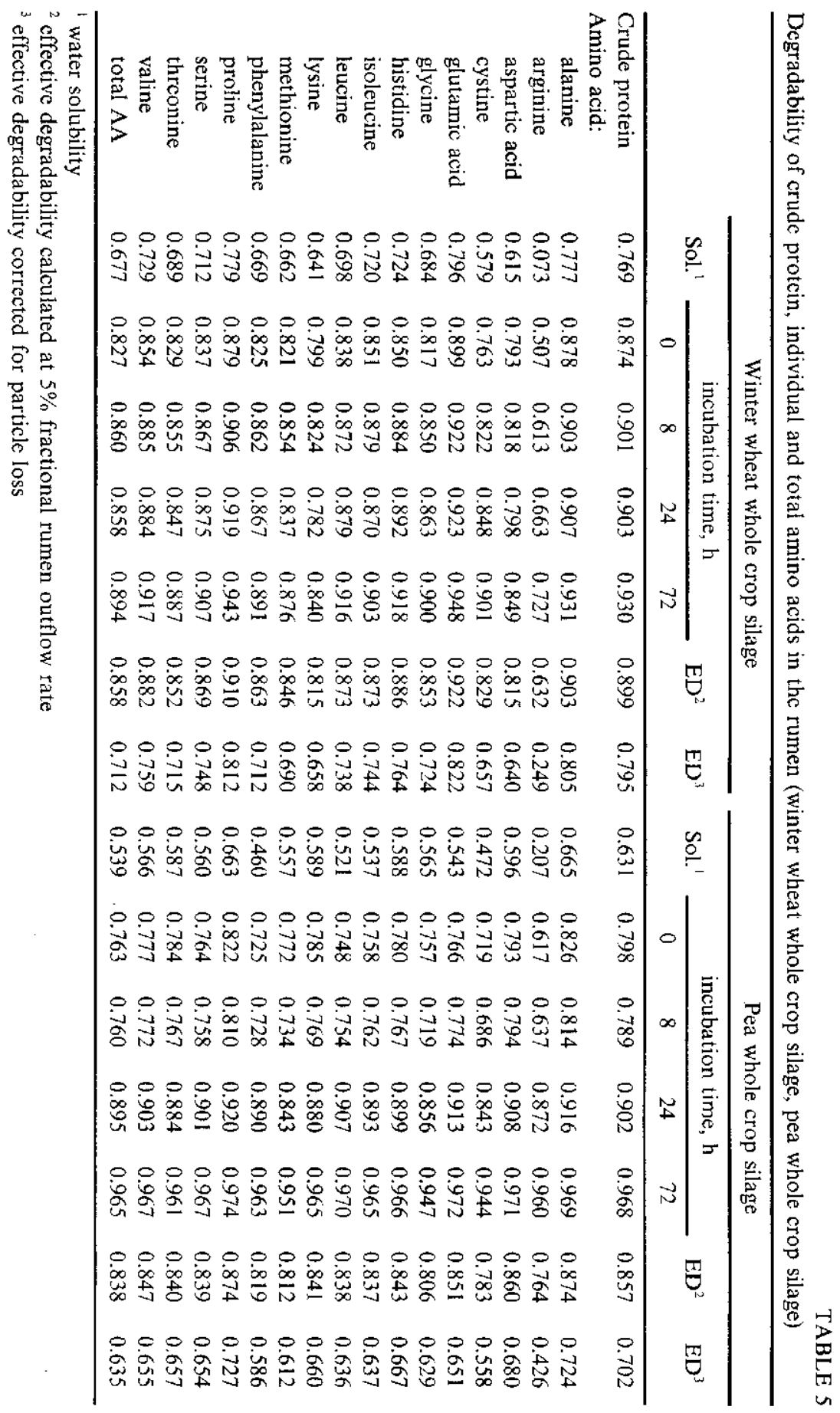


$\frac{6}{5}$

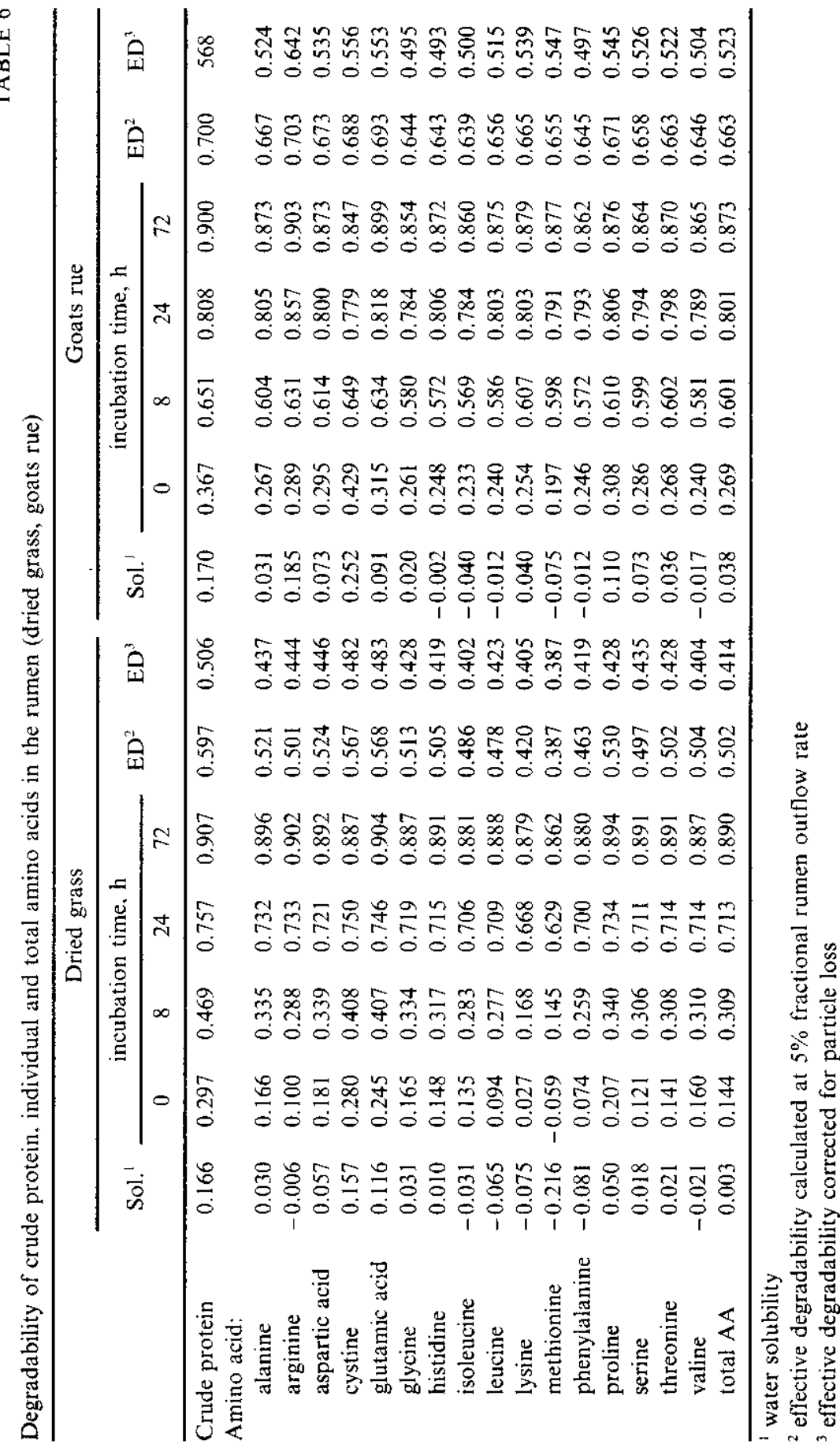




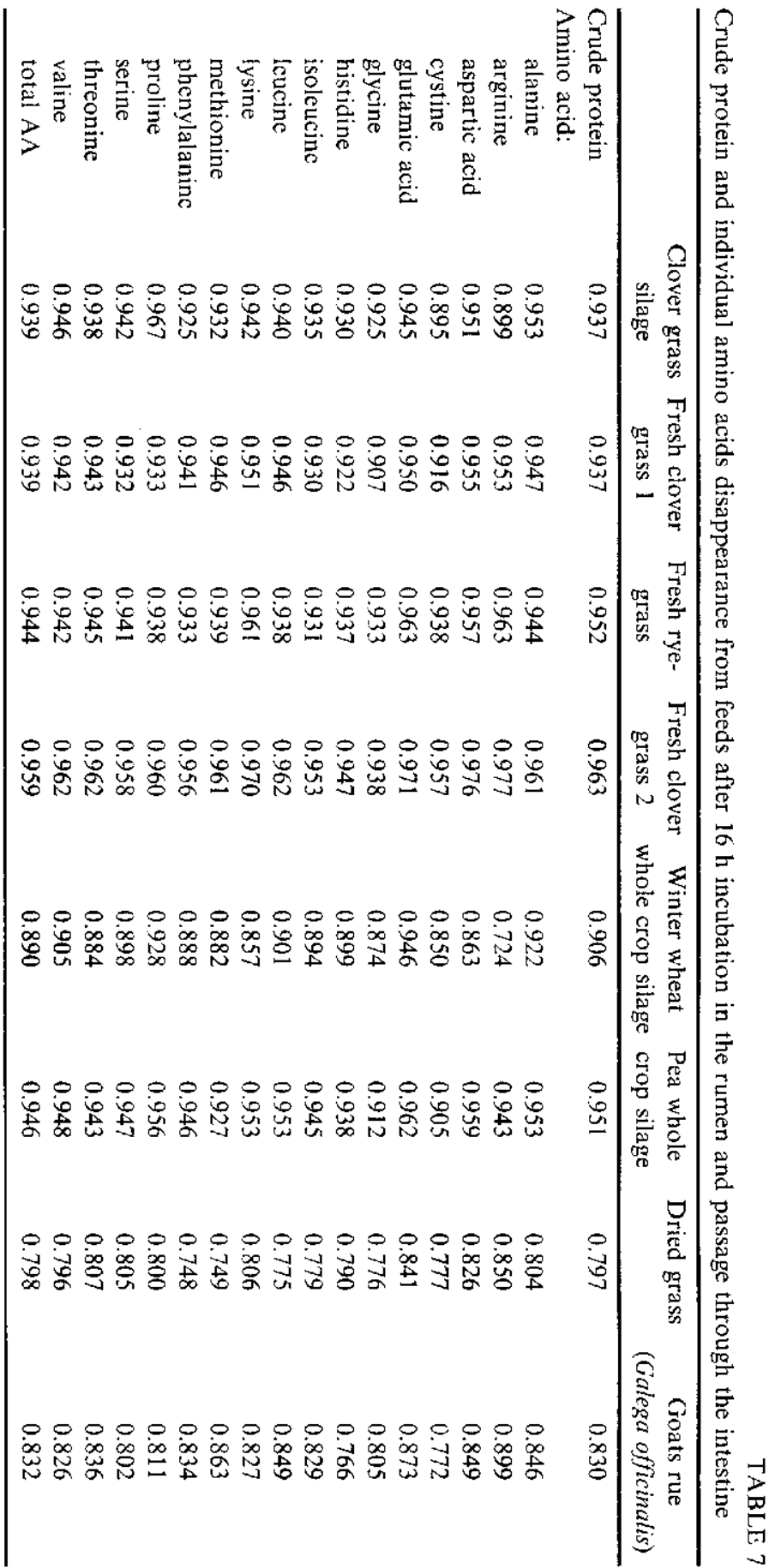


occurred between crude protein degradability and degradability of some individual AA, especially methionine which had the lowest degradability. Similar results were presented by Chalupa (1976) who showed that among essential AA, only methionine and valine had a lower degradability compared to total AA, but in that study the degradation of free AA was measured, whereas in the present study the degradability of AA-protein was mueasured. The low degradability of methionine was not confirmed in the present study in which degradability of methionine and lysine in most tested roughages were close to the degradability of total AA, especially for longer rumen incubation times. Only in dried grass the degradability of methionine was considerably lower than the degradabilities obtained for total AA. This was also observed for many other AA, such as lysine, isoleucine, leucine, phenylalanine and valine, all of which had low degradabilities. This was probably due to the heat treatment during the production process which may modify the degradation of protein and individual AA (Kerry et al., 1993; Dakowski et al., 1996).

Weisbjerg et al. (1996) found that the effective degradability of crude protein was a good predictor of effective degradability of total AA and lysine and methionine originating from concentrates, although in some feeds (cottonseed cake, palm kernel cake, maize gluten feed) the effective degradability of methionine could be overestimated. Susmel et al. (1989) showed that for feedstuffs tested in his study (soyabean meal, fish meal, dried brewers' and ensiled lucerne) methionine always had a higher degradability than total AA. High degradation of methionine was also observed in barley and barley straw (Varvikko, 1986) and in rapeseed meal (Setälä and Syrjälä-Qvist, 1984/85). According to Crooker et al. (1987) and Schfeifinger et al. (1976) the degradation of methionine depends on the nature of feedstuff, however, all branched-chain AA and especially lcucinc, isoleucine and phenylalanine, seems to be more resistant to microbial degradation in the rumen than the other AA. Tamminga (1979) suggests that cystine is also slowly degraded in comparison with other AA. In the present study cystine, glutamic acid and aspartic acid had the highest effective degradabilities in the tested fecds except for silages, while isoleucine, leucine and phenylalanine had the lowest degradabilities compared to total AA. Similar results were presented by Puchala et al. (1991), Kerry et al. (1993) and Weisbjerg et al. (1996).

Arginine has been assumed to be the most quickly degraded amino acid in the rumen (Chalupa, 1976; Tamminga, 1979; Mir et al., 1984; Cozzi et al., 1995; Dakowski et al., 1996), and according to Puchala et al. (1991), the degradability of arginine in plant proteins (particularly in lucerne hay, grass hay, maize and grass silage) is faster than in proteins of animal origin feeds. A substantial part of feed arginine is degraded during the ensiling process (Makoni et al., $1990 \mathrm{cf}$. Puchala et al., 1991). Arginine is metabolized to ornithine in the rumen (Lewis 
and Emery, $1962 \mathrm{a}, \mathrm{b})$ and if the same process takes place during ensiling, it can explain the high levels of ornithine often found in silage. $\Lambda$ comparison between silage and fresh feeds (clover grass) in Table 2 indicates that up to $2 / 3$ of the arginine has disappeared during ensiling, and that part of it can be found as ornithine. Therefore, arginine in silage will be the fraction which has not been degraded during ensiling, which probably is the most resistant fraction. This can explain the low rumen degradabilities found for arginine in silage. The ornithine in silage was nearly totally water soluble.

Disappearance from the mobile bags of total $\mathrm{AA}$ and crude protein in the present experiment was similar. This is in agreement with an earlier study of Weisbjerg et al. (1996) in which 15 concentrates were tested, and with results presented by Mupeta et al. (1996) for concentrates and tropical legume forages. Masoero et al. (1994) also showed that intestinal digestibility of total AA of undegraded protein residues was comparable with intestinal digestibility of protein for most feedstuffs, with some exceptions of poorly digestible and high fibre feeds. The above results indicate that intestinal crude protein digestibility could be a good predictor of intestinal AA digestibility. However, in other studies with intact and rumen undegraded protein, the higher digestibility of AA than of crude protein has been found for roughages (Skórko-Sajko et al., 1994) and for rapeseed meal (Dakowski et al., 1996).

In an in vivo study with concentrates Hvelplund and Hesselholt (1987) showed that digestibility of individual AA varied between and within feeds, and cystine was found to be the least digestible $\Lambda \Lambda$, although its digestibility varied from $42-76 \%$ depending on the source of undegraded protein. This was also confirmed by the studies of Skórko-Sajko et al. (1994), Dakowski et al. (1996) and Mupeta et al. (1996). The results of the present study indicate that cystine, but also glycine and sometimes histidine and phenylalanine, have a tendency to be less digestible than total AA. Erasmus et al. (1994) found that cystinc, proline, glycine and alanine are slightly less digestible than total AA. Although the results mentioned above indicate that cystine is the least digestible $\Lambda \mathrm{A}$, this cannot be accepted as a general fact as it was not observed in the studies of Masoero et al. (1994) and Weisbjerg et al. (1996), where the cystine of different concentrates had a similar or even higher digestibility than total AA.

The results of this study support the statement that the effective degradability of crude protein in the rumen is higher (mean difference 4.1 percentage points) than the effective degradability of total AA. Therefore, using the AA proportion of the feed protein as an estimate for the AA proportion of the rumen undegraded protein will result in a significant underestimation. Although arginine normally is readily degradable, it had a low degradability in this study, especially for silage samples and at short incubation times. This is probably due to previous degradation of the most available arginine during ensiling. The 
disappearance of crude protein and of total AA from the mobile bags were similar. This means that for roughages in this experiment disappearance of crude protein was a good estimate of both total AA disappearance and disappearance of most individual AA.

\section{ACKNOWLEDGMENTS}

The Danish Rectors' Conference is gratefully acknowledged for financial support of Beata Skiba's stay in Denmark. Mr. Ejner Serup's valuable technical assistance is thankfully acknowledged.

\section{REFERENCES}

AOAC, 1990. Official Methods of Analysis, Association of Official Analytical Chemists. 15th Edition, Washington, DC

ARC, 1984. The Nutrient Requirement of Ruminant Livestock. Agric. Res. Council, Suppl.I

Boila R.J., Ingalls J.R., 1994. The post-ruminal digestion of dry matter, nitrogen and amino acids in wheat-based distillers dried grains and cannola meal. Anim. Feed Sci. Technol. 49, 173-188

Chalupa W., 1976. Degradation of amino acids by mixed rumen microbial population. J. Anim. Sci. $43,828-834$

Cozzi G., Andrighetto J., Berzaghi, P., 1995. In situ ruminal disappearance of essential amino acids in protein feedstuffs. J. Dairy Sci. $78,161-171$

Crooker B.A.. Clark J.H., Shanks R.D., Fahey G.C., 1987. Effects of ruminal exposure on the amino acid protile of feeds. Can. J. Anim. Sci. 67, 1143-1148

Dakowski P., Weisbjerg M.R., Hvelplund T., 1996. The effect of temperature during processing of rape seed meal on amino acid degradation in the rumen and digestion in the intestine. Anim. Feed Sci. Technol. 58. 213-226

Erasmus L.J., Botha P.M., Cruywagen C.W., Meissner H.H., 1994. Amino acid profile and intestina] digestibility in dairy cows of rumen undegradable protein from various feedstuffs. J. Dairy Sci. $77,541-551$

Ganev G.O., Ørskov E.R., Smart R.M. 1979. The effect of roughage or concentrate feeding and rumen retention time on total degradability of protein in the rumen. J. Agric. Sci., Camb. 93, $651-656$

Hvelplund T., 1985. Digestibility of rumen microbial protein and undegraded dietary protein estimated in the small intestine of sheep or by in sacco procedure. Acta Agric. Scand., Suppl. 25, 132-144

Hvelplund T., Hesselholt M., 1987. Digcstibility of individual amino acids in rumen microbial protein and undegraded dietary protein in the small intestine of shecp. Acta Agric. Scand. 37, 469-477

Hvelplund T., Weisbjerg M.R., Andersen L.S., 1992. Estimation of the true digestibility of rumen undegraded dictary protein in the small intestinc of ruminants by the mobile bag technique. Acta Agric. Scand. Sect. A, Anim. Sci. 42, 34-39 
Kerry C.M., Amos H.E., Froetschel M.A., 1993. Effects of supplemental protein source on intraruminal fermentation, protein degradation and amino acid absorption. J. Dairy Sci., 76, 514-524

Lewis T.R., Emery, R.S., 1962a. Intermediate products in the catabolism of amino acids by rumen microorganisms. J. Dairy Sci. 45, 1363-1368

Lewis T.R., Emery R.S., 1962b. Metabolism of amino acids in the bovine rumen. J. Dairy. Sci. 45, 1487-1492

Madsen J., 1985. The basis for the proposed Nordic Protein Evaluation System for ruminants. The AAT-PBV System. Acta Agric. Scand., Suppl. 25, 9-20

Madsen J., Hvelplund T., 1994. Prediction of in situ degradability in the rumen. Results of an European ring test. Livest. Prod. Sci. 39, 201-212

Masoero F., Fiorentini L., Rossi F., Piva A., 1994. Determination of nitrogen intestinal digestibility in ruminants. Anim. Feed Sci. Technol. 48, 253-263

Mason V.C., Bech-Andersen S., Rudemo M., 1980. Hydrolysate preparation for amino acid determination in feed constituents. Z. Tierphysiol., Tierernähr. Futtermittelk. 43, 156-164

Mir L., MacLeod G.K., Buchanan-Smith J.G., Grieve D.G., Grovum W.L., 1984. Methods for protecting soyabean and canola proteins from degradation in the rumen. Can. J. Anim. Sci. 64, 853

Mupeta B., Weisbjerg M.R., Hvelplund T., Madsen J., 1996. Digestibility of amino acid in protein rich tropical feeds for ruminants estimated with the mobile bag technique. Anim. Feed Sci. Technol. (in press)

NKJ, 1985. Introduction of the proposed Nordic protein evaluation system for ruminants into practice and future research requirements. Acta Agric. Scand., Suppl. 25, 216-220

NRC, 1985. Ruminal nitrogen usage. National Academy Press, Washington, DC, pp. 138

Ørskov E.R., McDonald 1., 1979. The estimation of protein degradability in the rumen from incubation measurements weighted according to rate of passage. J. Agric. Sci., Camb. 92, 499-503

Puchala R., Shelford J.A., Vera A., Pior H., 1991. Degradability of amino acid from different feeds in the rumen. Proceedings of the $6^{\text {th }}$ International Symposium on Protein Metabolism and Nutrition. Vol. 2, 101-103

Rulquin H., Vcritć R., 1993. Amino acid nutrition of dairy cows: productive effects and animal requirements. In: C.P. Garnsworthy, D.J.A. Cole (Editors). Recent advances in animal nutrition, pp. 55-79

SAS, 1985. SAS User's Guide: Statistics. SAS Institute Inc., Box 8000, Cary, NC 27511. pp. 584

Schfeifinger C., Russel N., Chalupa W., 1976. Degradation of amino acids by pure cultures of rumen bacteria. J. Anim. Sci. 43, 821-827

Schwab C.G., Bozak C.K., Whitehouse N.L., Mesbah M.M.A., 1992. Amino acid limitation and flow to the duodenum at four stages of lactation. 1. Sequence of lysine and methionine limitation. J. Dairy Sci. 75, 3486

Setälä J., Syrjälä-Qvist L., 1984-85. Degradation of crude protein and quality of undegradable protein in untreated or formaldehyde-treated rapeseed meal. Anim. Feed Sci. Technol. 12, 19-27

Skórko-Sajko H., Hvelplund T., Weisbjerg M.R., 1994. Rumen degradation and intestinal digestibility of amino acids in different roughages estimated by nylon bag techniques. J. Anim. Fecd Sci. 3, 1-10

Susmel P., Stefanon B., Mills C.R., Candido, M., 1989. Change in amino acid composition of different protein sources after rumen incubation. Anim. Prod. 49, 375-383

Tamminga S., 1979. Protein degradation in the forestomachs of ruminants. J. Anim. Sci. 49, $1615-1630$ 
Teller E., Godean J.M., Van Nevel C.J., Demeyer D.J., 1985. Comparative in vitro and in vivo evaluation of protein degradability in the rumen using soyabean meal and Pruteen. J. Anim. Physiol. Anim. Nutr. 54, 121-130

Varvikko T., 1986. Microbially corrected amino acid composition of rumen undegraded feed protein and amino acid degradability in the rumen of feeds enclosed in nylon bags. Brit. J. Nutr. 56, $131-140$

Weakley D.C., Stern M.D., Satter L.D., 1983. Factors affecting disappearance of feedstuffs from bags suspended in the rumen. J. Anim. Sci. 56, 493-507

Weisbjerg M.R., Bhargava P.K., Hvelplund T., Madsen J., 1990. Use of degradation curves in feed evaluation (in Danish). Rep. 679, National Institute of Animal Science, Denmark, pp. 33

Weisbjerg M.R., Hvelplund T., Sanne S., Olsson S., Helberg S., 1996. Effective degradability in the rumen and intestinal digestibility of individual amino acids in different concentrates determined in situ. Anim Feed Sci. Technol. (in press)

\section{STRFSZCZENIE}

Rozkład w żwaczu i strawność jelitowa bialka i poszczególnych aminokwasów różnych pasz objętościowych oznaczona metodą in situ

W ośmiu różnych paszach objętościowych (kiszonka $\mathrm{z}$ koniczyny, 2 próby świcżcj koniczyny, rajgras, kiszonka $z$ calych roślin pszcnicy, kiszonka $z$ grochu, susz z trawy, rutwica lekarska) oznaczano, stosując metodę in situ, efektywny rozkład w żwaczu i rzeczywistą strawność jelitową biakka ogólnego, poszczególnych ammokwasów oraz sumy aminokwasów (AA).

Efeklywny rorkład w żwaczu białka ogólnego (przy tempie wypływu 5\%/godz.) był wyższy niż oznaczony dla sumy aminokwasów (różnice wynosiły od 1,9 do 4,1\%). Arginina byla najwolniej rozkładanym aminokwasem, zwłaszcza w kiszonkach i dla krótkich czasów inkubacji w żwaczı. Cysteina i fenyloalanina równiè wyka\%ywały tendencję do wolniejszego rozkładu niż suma AA. Najszybciej ubywającymi aminokwasami były alanina i prolina w kiszonkach oraz cysteina, kwas asparaginowy i glutaminowy w pozostałych paszach.

Ubytck sumy AA z woreczków mobilnych zawierających próbki pas\% po 16 god $z$. inkubacji w żwaczu wahał się od $79,8 \mathrm{w}$ suszu z traw do $95.9 \%$ w świeżej koniczynie i był podobny do ubytku biakka ogólnego wynoszącego, odpowiednio od 79,7 do $96 \%$.

W większości badanych pasz ubytek cysteiny i glicyny $z$ woreczków mobilnych był najmniejszy, a kwasu glutaminowego, asparaginowego $\mathrm{i}$ alaniny największy w porównaniu $\mathrm{z}$. wartościami uzyskanymi dla sumy AA. 